\title{
USE OF VEGETABLE OILS TO CONTROL BEAN WEEVIL DEVELOPMENT ON COWPEA GRAINS ${ }^{1}$
}

\author{
MARIA JOSÉ ARAÚJO WANDERLEY ${ }^{2 *}$, NIVÂNIA PEREIRA DA COSTA², THATIANA MARIA BORGES SILVA², \\ GEORGE RODRIGO BELTRÃO DA CRUZ ${ }^{3}$, THIAGO DE SOUSA MELO ${ }^{4}$
}

\begin{abstract}
Callosobruchus maculatus, commonly known as cowpea weevil, is the main pest affecting stored cowpea Vigna unguiculata. The damage resulting from the penetration and feeding of cowpea weevil larvae within the grains or seeds of $V$. unguiculata leads to weight loss, reduction of germination power and nutritional value and commercial depreciation of this plant. The objective of this work was to evaluate the insecticidal activity and repellency of vegetable oils extracted from fennel, citronella, neem and 'moringa' against $C$. maculatus adults. To evaluate the insecticidal activity, we placed 20 adult insects in plastic containers lined with filter paper impregnated with different doses $\left(0.0 \times 10^{6}, 5.0 \times 10^{6}, 1.0 \times 10^{5}, 1.5 \times 10^{5}, 2.0\right.$ $\times 10^{5}, 3.0 \times 10^{5}, 4.0 \times 10^{5}$ and $5.0 \times 10^{5} \mathrm{~L}$ ) of each vegetable oil. The number of insects was analyzed 24 hours later. To evaluate the repellency activity, we used an arena formed by five circular plastic containers with the central container interconnected symmetrically to the others by plastic tubes arranged diagonally. Samples of $30 \mathrm{~g}$ of cowpea were impregnated with different doses $\left(5.0 \times 10^{6}, 1.0 \times 10^{5}, 1.5 \times 10^{5}\right.$ and $\left.2.0 \times 10^{5} \mathrm{~L}\right)$ of each vegetable oil. We released 50 adults of $C$. maculatus in the central container and counted the number of insects per container 24 hours later. Citronella and fennel oils at a dose of $3.0 \times 10^{5} \mathrm{~L}$ demonstrated a higher insecticidal effect on C. maculatus. However, citronella oil presented the best repellent action.
\end{abstract}

Keywords: Callosobruchus maculatus. Stored grains. Natural insecticides. Preference Index. Vigna unguiculata.

\section{USO DE ÓLEOS VEGETAIS NO CONTROLE DO DESENVOLVIMENTO DO CARUNCHO DO FEIJÃO CAUPI}

RESUMO - Callosobruchus maculatus, conhecido como gorgulho do feijão caupi, é a principal praga que afeta o caupi armazenado Vigna unguiculata. Os danos resultantes da penetração e alimentação das larvas desse gorgulho nos grãos ou sementes do caupi levam à perda de peso, redução do poder de germinação e depreciação do valor nutricional e comercial desta planta. O objetivo deste trabalho foi avaliar a atividade inseticida e a repelência de óleos vegetais de erva-doce, citronela, nim e 'moringa' sobre adultos de $C$. maculatus. Para avaliar a atividade inseticida, foram colocados 20 insetos adultos em recipientes plásticos revestidos com papel filtro impregnado com doses diferentes $\left(0,0 \times 10^{6}, 5,0 \times 10^{6}, 1,0 \times 10^{5}, 1,5 \times 10^{5}, 2,0 \times\right.$ $10^{5}, 3,0 \times 10^{5}, 4,0 \times 10^{5}$ e $5,0 \times 10^{5} \mathrm{~L}$ ) de cada óleo vegetal. O número de insetos foi analisado após 24 horas. Para avaliar a atividade repelente, utilizou-se uma arena formada por cinco recipientes circulares plásticos, sendo o recipiente central interligado simetricamente aos demais por tubos plásticos dispostos diagonalmente. Amostras de $30 \mathrm{~g}$ do feijão foram impregnadas com diferentes doses $\left(5,0 \times 10^{6}, 1,0 \times 10^{5}, 1,5 \times 10^{5}\right.$ e $2,0 \times 10^{5}$ L) de cada óleo vegetal. Liberaram-se 50 adultos de C. maculatus no recipiente central e contados o número de insetos por recipiente 24 horas após a liberação. Os óleos de citronela e erva-doce na dose de $3,0 \times 10^{5} \mathrm{~L}$ demonstraram maior efeito inseticida sobre C. maculatus. No entanto, o óleo de citronela apresentou a melhor ação repelente.

Palavras-chave: Callosobruchus maculatus. Grãos armazenados. Inseticidas naturais. Índice de preferência. Vigna unguiculata.

\footnotetext{
${ }^{*}$ Corresponding author

${ }^{1}$ Received for publication in $03 / 21 / 2019$; accepted in 08/19/2019.

Paper extracted from the master dissertation of the third author.

${ }^{2}$ Department of Agriculture, Universidade Federal da Paraíba, Bananeiras, PB, Brazil; mjwander@gmail.com - ORCID: 0000-0002-23135771, costanp@yahoo.com.br - ORCID: 0000-0002-7935-4500, thatimaria@hotmail.com - ORCID: 0000-0001-8011-0784.

${ }^{3}$ Department of Animal Science, Universidade Federal da Paraíba, Bananeiras, PB, Brazil; georgebeltrao@hotmail.com - ORCID: 00000002-8480-4625.

${ }^{4}$ Center of Human, Social and Agrarian Sciences, Universidade Federal da Paraíba, Bananeiras, PB, Brazil; thiagosoumelo@hotmail.com ORCID: 0000-0003-1862-9571.
} 


\section{INTRODUCTION}

Vigna unguiculata L. (Walp), commonly known as cowpea, is a leguminous plant of important nutritional value widely cultivated in the warmest regions of Africa, Asia and Americas (MOREIRAARAÚJO et al., 2018). In Brazil, the cowpea presents a high socioeconomic importance, especially for arid and semi-arid regions, and is one of the main components in the Northeast region diet (ARAÚJO et al., 2018).

During storage period, pests such as Callosobruchus maculatus (Fabr.) (Coleoptera: Bruchidae), or cowpea weevil, can attack cowpea beans. Indeed, this species stands out among the main pests to stored grain (MARSARO JÚNIOR et al., 2005). C. maculatus females deposit their eggs in the seed's coat and, after 3-5 days, the larvae migrate into the seed's cotyledons, where they complete their life cycle (ADENEKAN; OKPEZE; OGUNTADE, 2013). This causes great damage to grains and seeds of stored beans, compromising their quality and use for planting (BAVARESCO, 2007).

Control of C. maculatus is often made using fumigant chemicals and synthetic insecticides. However, the use of these products in crop protection programs results in environmental imbalance, resistance and resurgence of pest insects, lethal effects to non-target organisms in agroecosystems, toxic residues in food and watercourses and toxicity to direct consumers (PRAKASH; RAO; NANDAGOPAL, 2008).

In the face of the many negative effects caused by the indiscriminate use of such products to the environment and health, several studies have been performed to find alternative means to reduce the use of these chemicals (ADENEKAN; OKPEZE; OGUNTADE, 2013; CAMPOS et al., 2014; ALVES et al., 2015). Among the different possibilities, bioactive products derived from the secondary metabolism of plants stands out as they are selective and present low persistence in the environment (SANTOS et al., 2012; FREIRE et al., 2016).

Several studies have reported the efficiency of the use of bioactive plants (powder, extract and oil) for controlling storage pests (RESTELLO; MENEGATT; MOSSI, 2009; GUSMÃO et al., 2013; CAMPOS et al., 2014; ALVES et al., 2015; OLIVEIRA et al., 2017). Cruz et al. (2012) studied the repellency of vegetable oils extracted from wild lavender Hyptis suaveolens, fennel Foeniculum vulgare and citronella Cymbopogon winteriannus against $C$. maculatus growing on cowpea grains. They concluded that citronella oil was more efficient to repel $C$. maculatus and recommended its use on grains stored worldwide. Oliveira et al. (2017) evaluated the fumigation and repellency of essential oils against $C$. maculatus growing on the cowpea. The authors observed that, in the fumigation test, Piper aduncum and eugenol showed a higher and lower lethal concentration (LC50) of 169.50 and $0.28 \mu \mathrm{L} \mathrm{L}^{-1}$ of oil, respectively. In the repellency test, oils of Syzygium aromaticum and Piper hispidinervum were repellent to $C$. maculatus.

In this study, we aimed to evaluate the insecticidal activity and repellency of vegetable oils extracted from fennel, citronella, neem and 'moringa' against C. maculatus adults in cowpea beans.

\section{MATERIAL AND METHODS}

\section{Insects rearing}

Callosobruchus maculatus rearing was carried out in the Entomology Laboratory from Paraíba Federal University (UFPB), Campus III. The insects were kept in $2.5 \mathrm{~L}$ glass containers with $V$. unguiculata grains, at room temperature, and covered with white 'voil' fabric. The 'voil' fabric fine texture allowed gas exchange between container and environment. Adult insects were kept on the grains for eight days after copulation and oviposition. After this period, the insects were removed and the container was left only with the seeds with postures leading to the F1 generation. The same procedures were performed to obtain the following generations.

\section{Acquisition of vegetable oils and bean grains}

The essential oils of citronella and fennel were obtained from the Entomology Laboratory at UFPB, Campus III. The oils were extracted by hydrodistillation or steam-dragging method in with $20 \mathrm{~kg}$ capacity. In order to extract the oils, the leaves, branches and stems of citronella and fennel plants were cut $20 \mathrm{~cm}$ above the ground. The collected plants were transported to the Entomology Laboratory, where they were weighed to select $20 \mathrm{~kg}$ of each plant for oil extraction. The fixed oil of 'moringa' seeds was obtained from the Chemical Engineering Laboratory at Sergipe Federal University (UFS), while the neem oil used was the commercial Neem Oil from Vitaplan ${ }^{\circledR}$. Cowpea beans, from the 'Cariri' cultivar used in the experiment, were acquired from family farmers of an agroecological street market in Solânea, state of Paraíba, Brazil. These beans were stored in a refrigerator at $10{ }^{\circ} \mathrm{C}$ until further experimentation, to avoid and inhibit insect infestations.

\section{Evaluation of insecticidal activity (Fumigation)}

Each experimental unit for the insecticidal activity evaluation was composed of 20 adults of $C$. maculatus. Prior to the experiments, the insects were fasted for 2 hours. The specimens were then placed into $250 \mathrm{~mL}$ plastic containers and covered by lids 
made with the same plastic material. These containers were lined with filter paper impregnated with each kind of oil (fennel, citronella, neem and 'moringa'). An automatic micropipette calibrated at several different doses $\left(0.0 \times 10^{6}, 5.0 \times 10^{6}, 1.0 \times\right.$ $10^{5}, 1.5 \times 10^{5}, 2.0 \times 10^{5}, 3.0 \times 10^{5}, 4.0 \times 10^{5}$ and $5.0 \times 10^{5} \mathrm{~L}$ ), according to Restello, Menegatt and Mossi (2009) was used to distribute the oils on the filter paper. C. maculatus was never in direct contact with the oil due to an adaptation, consisting of a $3 \mathrm{~mm}$ high circle of PVC (Polyvinyl Chloride) in the same diameter of the container. We coated the container's rim with EVA (Ethylene Vinyl Acetate) for better sealing and the circle was completely covered with filter paper. The disk was suspended inside the container and C. maculatus were released onto it. The fumigant action of each kind of oil was evaluated 24 hours after this procedure. Oil efficiency data were calculated according to Abbott (1987), using the following equation:

$$
\text { Efficacy }(\%)=\frac{x-y}{x} \times 100
$$

where: $x=$ percentage of live insects in the control; $y=$ percentage of living insects in the treated plot.

\section{Repellency evaluation}

The evaluation of the repellency exerted by fennel, citronella, neem and 'moringa' oils to $C$. maculatus was performed according to Restello, Menegatt and Mossi (2009). We used an arena for each kind of oil, consisting of five circular plastic containers $(25.0 \mathrm{~cm}$ in diameter and $6.5 \mathrm{~cm}$ in height each) with the central container symmetrically interconnected to the others by plastic tubes $(5.0 \mathrm{~cm}$ in diameter and $20.0 \mathrm{~cm}$ in length) arranged diagonally. We impregnated samples of 30 grams of cowpea grains with essential oils of citronella and fennel and with fixed oils of neem and 'moringa' before starting the assay. Repellency was tested individually for each kind of oil, at a dose of $5.0 \mathrm{x}$ $10^{6} ; 1.0 \times 10^{5} ; 1.5 \times 10^{5}$ and $2.0 \times 10^{5} \mathrm{~L}$, and grains treated with the oils were placed in two symmetrically opposed containers (A and B). In the other two opposite recipients (C and D), we placed the untreated cowpea grains (test), with four replicates for each treatment. In the central container (E), we released 50 adults of unsexed $C$. maculatus that had been fasted for 2 hours. The number of insects per container was counted 24 hours later. The Preference Index (P.I.) was calculated using data observed in the test, according to Procópio et al. (2003):

$$
\text { P. I. }=\frac{\% \text { IPT }-\% \text { Ipt }}{\% \text { IPT }+\% \text { Ipt }}
$$

where: P.I. $=$ Preference Index; $\%$ IPT $=\%$ of insects on the evaluated plant; $\% \mathrm{Ipt}=\%$ number of insects on test plant.

\section{Experimental design and statistical analysis}

To evaluate the insecticidal activity of each kind of oil in C. maculatus mortality, we applied a completely randomized design arranged in a 4x7 factorial scheme (four vegetal oils and seven doses), with five replicates of 20 specimens. To determine the attractiveness/repellency effect of each essential oil, a completely randomized design was also used, in a $4 \times 4$ factorial scheme (four oils and four doses), with four replicates of 50 specimens. Analyses of variance (ANOVA) were performed using the SAS GLM procedure (SAS INSTITUTE, 2012), and linear and quadratic regression tests were used to analyze the doses.

\section{RESULTS AND DISCUSSION}

\section{Evaluation of insecticidal activity (Fumigation)}

There was a significant interaction $(\mathrm{P}<0.0001)$ between vegetable oils and doses regarding insecticidal activity on $C$. maculatus (Table 1), as well as for the isolated factors (oils and doses).

Table 1. Variance analyses of the survival rate in Callosobruchus maculatus as a function of vegetable oils and doses on insecticidal activity.

\begin{tabular}{lllll}
\hline Source & GL & Mean Square & F-value & P-value \\
\hline Oil & 3 & 641.26 & 214.049 & $0.0000 \mathrm{e}+00$ \\
Dose & 5 & 285.45 & 95.283 & $0.0000 \mathrm{e}+00$ \\
Oil*Dose & 15 & 92.30 & 30.810 & $4.4732 \mathrm{e}-30$ \\
\hline
\end{tabular}

Specimens of $C$. maculatus submitted to $0.0 \mathrm{x}$ $10^{6}$ and $5.0 \times 10^{6} \mathrm{~L}$ doses of vegetable oils presented no significant differences in terms of survival (Table 2). On the other hand, doses of $1.0 \times 10^{5}, 1.5$ $\times 10^{5}, 2.0 \times 10^{5}, 3.0 \times 10^{5}, 4.0 \times 10^{5}$ and $5.0 \times 10^{5} \mathrm{~L}$ interfered $(\mathrm{P}<0.0001)$ with survival. When comparing the effect of the different oils at a dose of $1.0 \times 10^{5}$ and $2.0 \times 10^{5} \mathrm{~L}$, citronella oil caused lower insect survival. When comparing the effect of the different oils at a dose of $1.5 \times 10^{5} ; 3.0 \times 10^{5} ; 4.0 \times$ $10^{5}$ and $5.0 \times 10^{5} \mathrm{~L}$, C. maculatus presented lower survival rates with fennel and citronella oils. These results show that fennel and citronella oils had higher insecticidal activity on the insects than the other oils. 
M. J. A. WANDERLEY et al.

Table 2. Survival rates breakdown of Callosobruchus maculatus as a function of vegetable oils and doses on insecticidal activity.

\begin{tabular}{|c|c|c|c|c|c|c|}
\hline \multirow{2}{*}{$\begin{array}{l}\text { Doses } \\
\text { (L) }\end{array}$} & \multicolumn{4}{|c|}{ Vegetable oils } & \multirow{2}{*}{ Mean } & \multirow{2}{*}{$\mathrm{SE}$} \\
\hline & Fennel $^{\mathrm{Q}}$ & Citronella $^{\mathrm{Q}}$ & Neem $^{\text {ns }}$ & 'Moringa'L & & \\
\hline $0.0 \times 10^{6}$ & $19.60 \pm 0.5 \mathrm{a}$ & $19.20 \pm 0.8 \mathrm{a}$ & $17.60 \pm 1.1 \mathrm{a}$ & $18.80 \pm 0.8 \mathrm{a}$ & $18.80 \pm 1.1$ & \\
\hline $5.0 \times 10^{6}$ & $17.60 \pm 0.9 \mathrm{a}$ & $17.60 \pm 2.4 \mathrm{a}$ & $17.40 \pm 1.5 \mathrm{a}$ & $19.80 \pm 0.4 \mathrm{a}$ & $18.10 \pm 1.7$ & \\
\hline $1.0 \times 10^{5}$ & $18.20 \pm 1.3 \mathrm{a}$ & $14.40 \pm 4.5 b$ & $18.00 \pm 1.6 \mathrm{a}$ & $18.80 \pm 0.8 \mathrm{a}$ & $17.35 \pm 2.9$ & \\
\hline $1.5 \times 10^{5}$ & $13.80 \pm 1.3 b$ & $11.60 \pm 1.5 b$ & $17.60 \pm 1.8 \mathrm{a}$ & $20.00 \pm 0.0 \mathrm{a}$ & $15.75 \pm 3.6$ & \\
\hline $2.0 \times 10^{5}$ & $16.60 \pm 1.5 b$ & $8.20 \pm 1.9 \mathrm{c}$ & $17.80 \pm 0.8 \mathrm{ab}$ & $19.60 \pm 0.5 \mathrm{a}$ & $15.55 \pm 4.7$ & 1.0 \\
\hline $3.0 \times 10^{5}$ & $1.80 \pm 0.8 \mathrm{c}$ & $4.60 \pm 1.1 b$ & $18.60 \pm 1.3 \mathrm{a}$ & $17.00 \pm 1.4 \mathrm{a}$ & $10.50 \pm 7.7$ & \\
\hline $4.0 \times 10^{5}$ & $2.60 \pm 1.8 \mathrm{~d}$ & $5.40 \pm 1.9 \mathrm{c}$ & $18.60 \pm 0.9 \mathrm{a}$ & $15.40 \pm 3.0 \mathrm{~b}$ & $10.50 \pm 7.1$ & \\
\hline $5.0 \times 10^{5}$ & $3.60 \pm 2.4 \mathrm{c}$ & $5.00 \pm 1.2 \mathrm{c}$ & $18.80 \pm 0.8 \mathrm{a}$ & $15.80 \pm 1.6 \mathrm{~b}$ & $10.80 \pm 7.0$ & \\
\hline Mean & $11.73 \pm 7.4$ & $10.75 \pm 5.9$ & $18.05 \pm 1.3$ & $18.15 \pm 2.1$ & $\mathrm{CV}, \%=11.32$ & \\
\hline
\end{tabular}

${ }^{a, b}$ Means followed by different lowercase in the same line are different to each kind of vegetable oil according to the Duncan Test $(\mathrm{P}<0.05) ; \mathrm{Q}=$ quadratic regression effect; $1=$ linear regression effect, $\mathrm{ns}=$ not significant; $\mathrm{CV}=$ coefficient of variation; $\mathrm{SE}=$ standard error.

Several studies have confirmed the efficacy of fixed oils in the control of $C$. maculatus. According to Alves et al. (2015), who investigated the fumigant potential of essential oils in the control of $C$. maculatus life cycle, oils from Ocimum basilicum, Cymbopogon nardus, C. citratus, Lippia alba, Mentha arvensis, and Schinus terebinthifolius provided more than $80 \%$ inhibition of egg laying and more than $98 \%$ decrease of newborn insects.

Figure 1 represents the polynomial regression analysis for doses per kind of oil evaluated. Doses of citronella and fennel oils adjusted to the quadratic model $(\mathrm{P} \leq 0.05)$, while 'moringa' vegetable oil adjusted to the linear model $(\mathrm{P} \leq 0.05)$. On the other hand, the levels used for neem vegetable oil showed no polynomial regression effect $(\mathrm{P}>0.05)$.

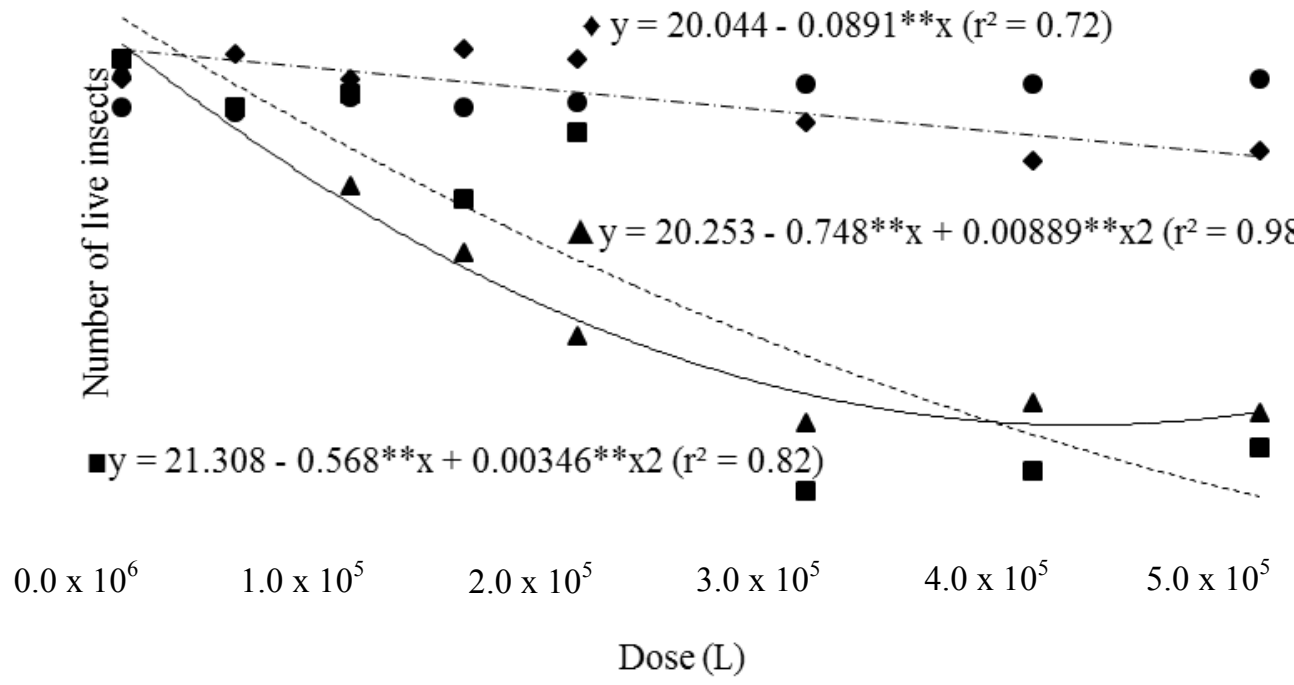

Figure 1. Polynomial regression analyses of the effect of different doses of oils extracted from fennel $F$. vulgare (匹), citronella $C$. winterianus $(\boldsymbol{\Delta})$, 'moringa' M. oleifera $(\bullet)$ and neem $A$. indica $(\bullet)$ on the survival of adult $C$. maculatus.

The doses of 'moringa' oil induced a linear decreasing effect on the number of C. maculatus specimens evaluated (Figure 1). However, there was a quadratic effect $(\mathrm{P} \leq 0.05)$ as a function of the increasing doses of citronella and fennel oils on the number of C. maculatus individuals: 20 and 21 individuals, respectively, did not survive at the estimated doses of $4.2 \times 10^{5}$ and $8.2 \times 10^{5} \mathrm{~L}$.

According to Gusmão et al. (2013) citronella contains geranial and citronellal, while fennel presents limonene, (E)-anethole and a-pinene, which are generally considered responsible for the bioactivity of essential oils. Citronellal is a toxic agent present in the essential oils of species such as Corymbia citriodora and Cymbopogon nardus, which show toxicity to the maize weevil Sitophilus zeamais (OOTANI et al., 2011). Limonene is a monoterpene (DIAS et al., 2019) that can exert toxicity through different pathways, affecting the insects by penetrating their cuticles and respiratory 
system or by ingestion (PRATES et al., 1998). It is likely that the chemical constituents present in citronella and fennel oils affected the respiratory system of the specimens used in our study as the insecticidal activity assays were performed using fumigation and $C$. maculatus was never in direct contact with the oils.

\section{Repellency evaluation}

We observed interaction between the vegetable oils and doses evaluated $(\mathrm{P}=0.0237)$ regarding the attractiveness of live $C$. maculatus adults (Table 3) but not regarding repellency $(\mathrm{P}>0.05)$.

Table 3. Mean values of live C. maculatus attracted and repelled as a function of vegetable oils and doses on insecticide activity.

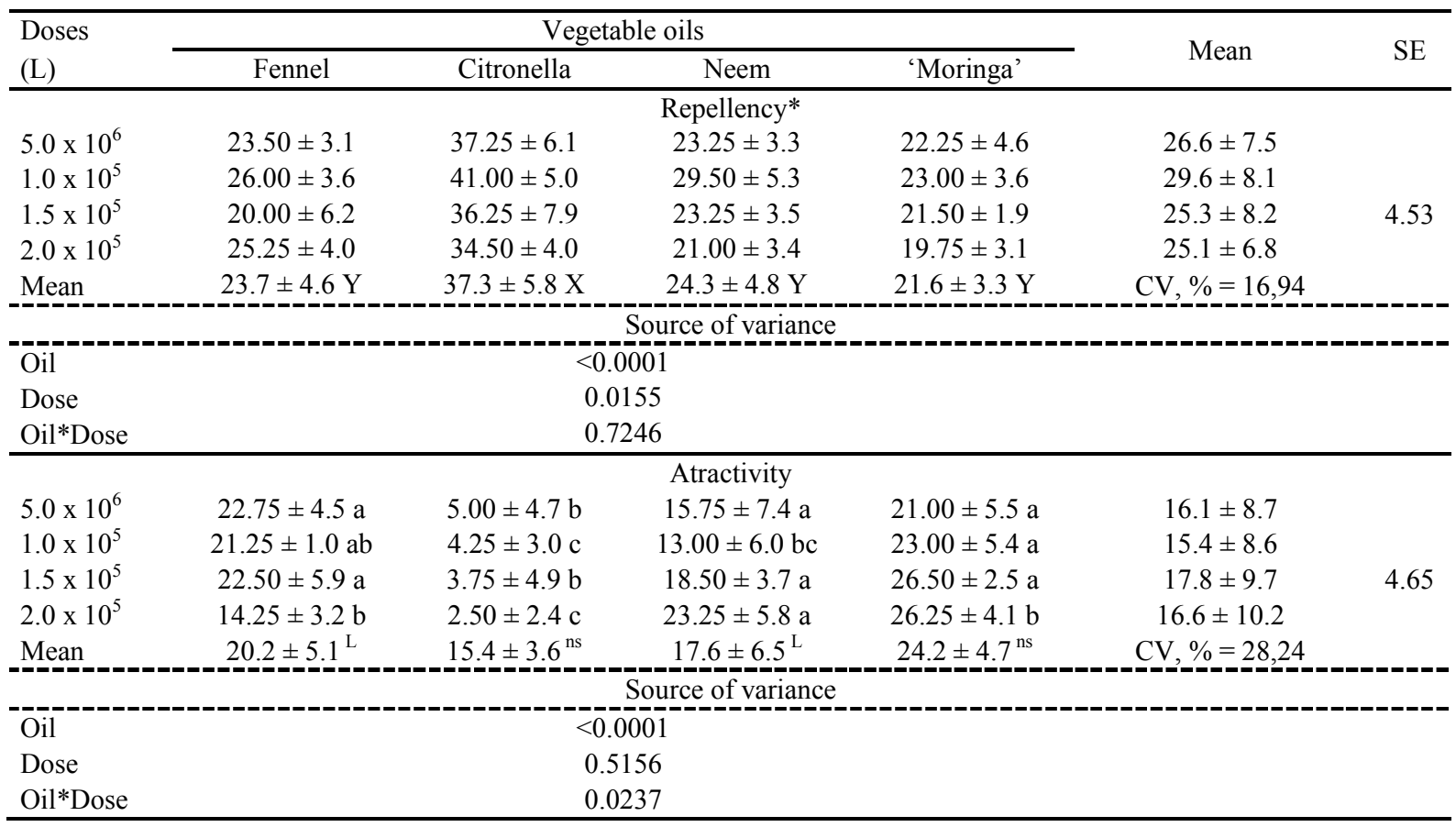

${ }^{\mathrm{a}, \mathrm{b}}$ Means followed by different lowercase letters in the same line are different to each kind of vegetable oil according to the Duncan Test $(\mathrm{P}<0.05)$;

${ }_{\mathrm{X}, \mathrm{Y}}$ Means followed by different uppercase letters in the same line are different according to the Duncan Test $(\mathrm{P}<0.05)$;

*Regression effect not significant to increased doses of vegetable oils.

$\mathrm{L}=$ linear regression effect, $\mathrm{ns}=$ not significant; $\mathrm{CV}=$ coefficient of variation.

The different kinds of vegetable oils interfered with the attractiveness and repellency against $C$. maculatus live adults $(\mathrm{P}<0.0001)$ and the increasing doses of vegetable oils affected the repellency against live adult insects $(\mathrm{P}=0.0155)$. However, the attractiveness was not significant $(\mathrm{P}>0.05)$ in function of increasing doses of vegetable oils (Table 3 ).

Analyzing the statistical breakdown among the evaluated vegetable oils, we observed that citronella oil had the lowest insect attractiveness at all doses studied (Table 3). Citronella oil had a lower attractive effect than the other vegetable oils regardless of the dose $(5.00 \pm 4.7,4.25 \pm 3.0$, $3.75 \pm 4.90$ and $2.50 \pm 2.4$, respectively, for the doses of $5.0 \times 10^{6}, 1.0 \times 10^{5}, 1.5 \times 10^{5}$ and $2.0 \times 10^{5} \mathrm{~L}$ ).

Figure 2 shows the polynomial regression analysis for doses as a function of each kind of oil in terms of attractiveness of $C$. maculatus. The doses of fennel and neem oils adjusted to the linear model $(\mathrm{P} \leq 0.05)$. On the other hand, the evaluated doses of citronella and 'moringa' oils did not present a polynomial regression effect $(\mathrm{P}>0.05)$. 


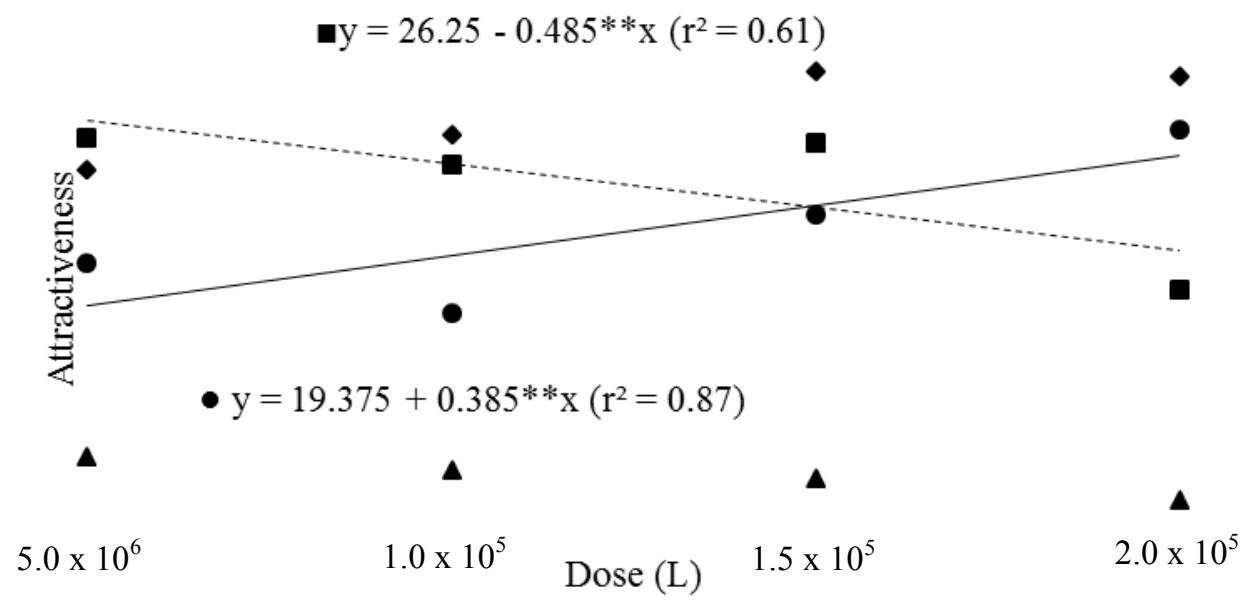

Figure 2. Linear regression analysis of the effect of different doses of oils extracted from fennel $F$. vulgare (๘), citronella C. winterianus $(\mathbf{\Delta})$, 'moringa' M. oleifera $(\diamond)$ and neem $A$. indica $(\bullet)$ on the attractiveness of $C$. maculatus adults.

Neem oil attracted a greater number of insects as the dose increased, whereas the opposite occurred with fennel oil. However, although it did not show a polynomial regression effect, citronella oil presented the lowest value of attractiveness of all the oils tested in this study, thereby confirming its repellent and insecticidal action (Figure 2). The result of the present research agrees with data obtained by Cruz et al. (2012). These authors concluded that citronella oil is effective on $C$. maculattus repellency when used at $2 \%$, and it may be considered an important tool for the protection of stored grains, mainly for small farmers.

Oliveira et al. (2017) evaluated the fumigant and repellent effects of eight essential oils on $C$. maculatus growing on cowpea grains. S. aromaticum and Cinnamomum zeylanicum oils presented potential for $C$. maculatus management via fumigation in stored cowpea, presenting toxicity even at low concentrations and showing high efficiency against this pest. However, $S$. aromaticum and Piper hispidinervum oils presented repellency against these insects.

Citronella oil presented a higher repellency value $(37.25 \pm 5.8)$ compared to other vegetable oils (Table 3). Generally, essential oils have been used as fumigant, systemic and contact insecticides, and as insect repellents in the control of stored grain pests (BAKKALI et al., 2008).

Al-Jabr (2006) found that citronella oil at 1\% caused $100 \%$ mortality of Tribolium castaneum and concluded that this oil may be very important to control stored grain insects. Regarding repellency, Cruz et al. (2012) observed that citronella oil at $2 \%$ attracted fewer adult insects of $C$. maculatus (average of 1.76 individuals) compared to lavender and fennel oils (average of 3,52 and 6,72 individuals, respectively). Gusmão et al. (2013) evaluated doses of $178.13,298.17,328.42$ and $345.57 \mathrm{ppm}$ of citronella oil and found that these concentrations caused repellency against $C$. maculatus.

The results obtained regarding the Preference Index (P.I.) (Table 4) of C. maculatus to the vegetable oils showed that, at the doses used, citronella oil was repellent against adults of $C$. maculatus. All doses of fennel oil tested were neutral; neem oil was repellent at $5.0 \times 10^{6}$ and $1.0 \mathrm{x}$ $10^{5} \mathrm{~L}$ and neutral at the $1.5 \times 10^{5}$ and $2.0 \times 10^{5} \mathrm{~L}$ doses; 'moringa' oil had a neutral effect at doses from $5.0 \times 10^{6}$ to $1.5 \times 10^{5} \mathrm{~L}$, while the dose of $2.0 \mathrm{x}$ $10^{5} \mathrm{~L}$ was attractive to $C$. maculatus adults.

According to Alves et al. (2001), large numbers of insect species need substances present in plants as free amino acids, as these animals are not able to break proteins into amino acids. When studying 'moringa's' nutritional values, Moyo et al. (2011) listed 19 different amino acids present in their leaves. The fact that 'moringa' is a plant rich in amino acids may have been a positive factor on $C$. maculatus attractiveness in the present study. 
Table 4. Preference Index and Classification of C. maculatus to vegetable oils on Vigna unguiculata.

\begin{tabular}{llcr}
\hline Oil & Dose $(\mathrm{L})$ & P.I. & Classification \\
\hline Fennel & $5.0 \times 10^{6}$ & -0.0155 & Neutral \\
Fennel & $1.0 \times 10^{5}$ & -0.0937 & Neutral \\
Fennel & $1.5 \times 10^{5}$ & 0.1075 & Neutral \\
Fennel & $2.0 \times 10^{5}$ & -0.0729 & Neutral \\
Citronella & $5.0 \times 10^{6}$ & -0.7527 & Repellent \\
Citronella & $1.0 \times 10^{5}$ & -0.8000 & Repellent \\
Citronella & $1.5 \times 10^{5}$ & -0.7257 & Repellent \\
Citronella & $2.0 \times 10^{5}$ & -0.6491 & Repellent \\
Neem & $5.0 \times 10^{6}$ & -0.1628 & Repellent \\
Neem & $1.0 \times 10^{5}$ & -0.3297 & Repellent \\
Neem & $1.5 \times 10^{5}$ & -0.0971 & Neutral \\
Neem & $2.0 \times 10^{5}$ & 0.0819 & Neutral \\
'Moringa' & $5.0 \times 10^{6}$ & -0.0113 & Neutral \\
'Moringa' & $1.0 \times 10^{5}$ & 0.0000 & Neutral \\
'Moringa' & $1.5 \times 10^{5}$ & 0.0918 & Neutral \\
'Moringa' & $2.0 \times 10^{5}$ & 0.1398 & Attractive \\
\hline
\end{tabular}

P.I.: Preference Index.

According to Procópio et al. (2003), results of P.I. between -1.0 and -0.10 indicate a repellent effect to the essential oil tested. However, values between 0.10 and 0.10 correspond to neutral effects and values between 0.10 and 1.0 correspond to attractive effects.

Few studies have been found calculating the P.I. of essential oils on $C$. maculatus growing on cowpea. However, Campos et al. (2014) evaluated the P.I. of the essential oil extracted from the groundsel bush Baccharis articulata on Acanthoscelides obtectus growing on black beans of Phaseolus vulgaris. All tested doses of $1.0 \times 10^{5}, 2.0$ $\mathrm{x} 10^{5}, 3.0 \times 10^{5}, 5.0 \times 10^{5}$ and $1.0 \times 10^{4} \mathrm{~L}$ of this oil presented repellency to $A$. obtectus. These results corroborate with the data presented in our study using $5.0 \times 10^{6}, 1.0 \times 10^{5}, 1.5 \times 10^{5}$ and $2.0 \times 10^{5} \mathrm{~L}$ doses of citronella oil and $5.0 \times 10^{6}$ and $1.0 \times 10^{5} \mathrm{~L}$ of neem oil. According to Coitinho et al. (2006), the repellent action is an important aspect to be considered in the control of insect-pests of stored products, because the greater the repellency, the lower the infestation, which in turn reduces or suppresses posture leading to a lower number of newborn insects.

\section{CONCLUSIONS}

Vegetable oils at a dose of $3.0 \times 10^{5} \mathrm{~L}$ extracted from citronella and fennel showed the greatest insecticidal effect on adults of $C$. maculatus.

Citronella oil presented the best repellent action against $C$. maculatus adults.

\section{REFERENCES}

ABBOTT, W. S. A method of computing the effectiness of an insecticide. Journal of the
American Mosquito Control Association, v. 3, n. 2, p. 302-303, 1987.

ADENEKAN, M. O.; OKPEZE, V. E.; OGUNTADE, M. I. Evaluation of Moringa oleifera powders for the control of bruchids beetles during storage. International Journal of Agricultural Policy and Research, v. 10, n. 10, p. 305-310, 2013.

AL-JABR, A. M. Toxicity and repellency of seven plant essential oils to Oryzaephilus surinamensis (Coleoptera: Silvanidae) and Tribolium castaneum (Coleoptera: Tenebrioidae). Scientific Journal of King Faisal University, v. 7, n. 1, p. 49-60, 2006.

ALVES, S. B. et al. Trofobiose e Microrganismos na Proteção de plantas. Biotecnologia Ciência \& Desenvolvimento, v. 21, s/n., p. 16-21, 2001.

ALVES, M. S. et al. Essential Oils Composition and Toxicity Tested by Fumigation Against Callosobruchus maculatus (Coleoptera: Bruchidae) Pest of Stored Cowpea. Revista Virtual de Química, v. 7, n. 6, p. 2387-2399, 2015.

ARAÚJO, E. D. et al. Germination and initial growth of cowpea cultivars under osmotic stress and salicylic acid. Revista Caatinga, v. 31, n. 1, p. 8089, 2018.

BAKKALI, F. et al. Biological effects of essential oils: a review. Food and Chemical Toxicology, v. 46, n. 2, p. 446-475, 2008.

BAVARESCO, A. Avaliação de tratamentos alternativos para o controle de Acanthoscelides obtectus (Say) (Coleoptera: Bruchidae). Revista de Ciências Agroveterinárias, v. 6, n. 2, p. 125-133, 2007. 
CAMPOS, A. C. T. et al. Atividade repelente e inseticida do óleo essencial de carqueja doce sobre o caruncho do feijão. Revista Brasileira de Engenharia Agrícola e Ambiental, v. 18, n. 8, p. 861-865, 2014.

COITINHO, R. L. B. C. et al. Atividade inseticida de óleos essenciais sobre Sitophilus zeamais Mots (COLEOPTERA: CURCULIONIDAE) em milho armazenado. Revista Caatinga, v. 19, n. 2, p. 176182, 2006.

CRUZ, C. S. A. et al. Repelência do Callosobruchus maculatus (COLEOPTERA: BRUCHIDAE) sobre grãos de feijão caupi tratado com óleos vegetais. Revista Verde de Agroecologia e Desenvolvimento Sustentável, v. 7, n. 3, p. 1-5, 2012.

DIAS, A. L. B. et al . Chemical composition and in vitro inhibitory effects of essential oils from fruit peel of three Citrus species and limonene on mycelial growth of Sclerotinia sclerotiorum. Brazilian Journal of Biology, s/v., s/n., p. 1-5, 2019.

FREIRE, G. F. et al. Bioatividade de Solanum melongena L. e Capsicum annuum L. sobre Callosobruchus maculatus (COLEOPTERA: BRUCHIDAE). Acta Biológica Colombiana, v. 21, n. 1, p. 123-130, 2016.

GUSMÃO, N. M. S. et al. Contact and fumigant toxicity and repellency of Eucalyptus citriadora Hook., Eucalyptus staigeriana F., Cymbopogon winteranus Jowitt and Foeniculum vulare Mill. essential oils in the management of Callosobruchus maculatus (FABR.) (Coleoptera: Chrysomelidae, Bruchinae). Journal of stored Products Research, v. 54, s/n., p. 41-47, 2013.

MARSARO JÚNIOR, A. L. et al. Inibidores de amilase em híbridos de milho como fator de resistência a Sitophilus zeamais Motschulsky (Coleoptera: Curculionidae). Neotropical Entomology, v. 34, n. 3, p. 443-450, 2005.

MOREIRA-ARAÚJO, R. S. R. et al. Identification and quantification of phenolic compounds and antioxidant activity in cowpeas of brs xiquexique cultivar. Revista Caatinga, v. 31, n. 1, p. 209-216, 2018.

MOYO, B. et al. Nutritional characterization of Moringa (Moringa oleifera Lam.) leaves. African Journal of Biotechnology, v. 10, n. 60, p. 12925 12933, 2011.

OLIVEIRA, J. V. et al. Fumigation and repellency of essential oils against Callosobruchus maculatus
(Coleoptera: Chrysomelidae: Bruchinae) in cowpea. Pesquisa Agropecuária Brasileira, v. 52, n. 1, p. 10 $-17,2017$.

OOTANI, M. A. et al. Toxicidade de óleos essenciais de eucalipto e citronela sobre Sitophilus zeamais Motschulsky (Coleoptera: Curculionidae). Bioscience Journal, v. 27, n. 4, p. 609-618, 2011

PRAKASH, A.; RAO, J.; NANDAGOPAL, V. Future of botanical pesticides in rice, wheat, pulses and vegetables pest management. Journal of Biopesticides, v. 1, n. 2, p. 154-169, 2008.

PRATES, H. T. et al. Insecticidal activity of monoterpenes against Rhyzopertha dominica (F.) and Tribolium castaneum (Herbst). Journal of Stored Products Research, v. 34, n. 4, p. 243-249, 1998.

PROCÓPIO, S. O. et al. Bioatividade de diversos pós de origem vegetal em relação a Sitophilus zeamais Mots (Coleoptera:Curculionidae). Ciência e Agrotecnologia, v. 27, n. 6, p. 1231-1236, 2003.

RESTELLO, R. M.; MENEGATT, C.; MOSSI, A. J. Efeito de óleo de Tagetes patula L. (Asteraceae) sobre Sitophilus zeamais Motschulsky (Coleoptera: Curculionidae). Revista Brasileira de Entomologia, v. 53 , n. 2, p. $304-307,2009$

SANTOS, O. O. et al. Atividade inseticida de produtos de origem vegetal sobre moscas-das-frutas (Diptera: Tephritidae) e broca-rajada (Coleoptera: Curculionidae). Magistra, v. 24, sup., p. 26-31, 2012.

SAS, Institute Inc. SAS/STAT User's guide. Cary, North Caroline: SAS Institute Inc., 2012. 